\title{
Photograph as Skin, Skin as Wax: Indexicality and the Visualisation of Syphilis in Fin-de-Siècle France The William Bynum Prize Essay
}

\author{
KATHLEEN PIERCE * \\ 71 Hamilton Street, Voorhees Hall, New Brunswick, NJ 08901, USA
}

\begin{abstract}
In early twentieth-century France, syphilis and its controversial status as a hereditary disease reigned as a chief concern for physicians and public health officials. As syphilis primarily presented visually on the surface of the skin, its study fell within the realms of both dermatologists and venereologists, who relied heavily on visual evidence in their detection, diagnosis, and treatment of the disease. Thus, in educational textbooks, atlases, and medical models, accurately reproducing the visible signposts of syphilis - the colour, texture, and patterns of primary chancres or secondary rashes - was of preeminent importance. Photography, with its potential claims to mechanical objectivity, would seem to provide the logical tool for such representations.
\end{abstract}

Yet photography's relationship to syphilographie warrants further unpacking. Despite the rise of a desire for mechanical objectivity charted in the late nineteenth century, artist-produced, three-dimensional, wax-cast moulages coexisted with photographs as significant educational tools for dermatologists; at times, these models were further mediated through photographic reproduction in texts. Additionally, the rise of phototherapy complicated this relationship by fostering the clinical equation of the light-sensitive photographic plate with the patient's skin, which became the photographic record of disease and successful treatment. This paper explores these complexities to delineate a more nuanced understanding of objectivity vis-à-vis photography and syphilis. Rather than a desire to produce an unbiased image, fin-de-siècle

\footnotetext{
* Email address for correspondence: Kathleen.Pierce@Rutgers.edu
}

I owe many people a debt of gratitude for their contributions to this paper. Research for this paper was first presented at the conference 'Envisioning Science', organised by the Natura Science and Epistemology Working Group at Rutgers University; I thank the organisers and attendees alike for their questions, comments and feedback. An early version of the paper was also shared with the History of Dermatology Society, and I thank members of the society, especially Mark Valentine, Lawrence Parish, and Daniel Wallach, for their interest in the project. It was also due to the generosity of a bursary from the Society for the Social History of Medicine that I was able to share my work with the History of Dermatology Society, and I owe the SSHM my gratitude for enabling me to attend what became an incredibly formative conference. Andrés Zervigón, Susan Sidlauskas, Kaitlin Booher, and Kimiko Matsumura all reviewed portions of the manuscript at various stages of production, and I thank them for their sharp insights. I would also like to thank the archivists and librarians at the Wellcome Collection, the Archives AP - HP, the Dittrick Museum of Medical History, and the Musée des moulages and Bibliothèque Henri Feulard at the hôpital Saint-Louis, especially Sylvie Dorison and Marie Barthélemy, for sharing their knowledge and for their unflagging collegiality. Finally, I would like to thank Professor William Bynum and the William Bynum Essay Prize Awarding Committee for their recognition and support, and for providing the opportunity to continue developing this research. 
dermatologists marshalled the photographic to exploit the verbal and visual rhetoric of objectivity, authority, and persuasion inextricably linked to culturally constructed understandings of the photograph. This rhetoric was often couched in the Peircean concept of indexicality, which physicians formulated through the language of witness, testimony, and direct connection.

Keywords: Syphilis, Objectivity, Photography, Medical models, Visual culture, Skin

In his 1912 Syphilis héréditaire de l'âge adulte [Hereditary Syphilis in Adulthood], the syphilographer Edmond Fournier, son of the famed syphilographer Alfred Fournier, published three images of a syphilitic patient taken between 1888 and 1899 (Figures 1, 2 , and 3). Fournier furnishes the trio of images, originally photographed by his father, as evidence of the 'slow', 'torpid', 'chronic', and recurring nature of gummas, sores typical of the tertiary phase of syphilis. ${ }^{1}$

All three photographs exploit a solid black background against which the patient's leg stands in stark contrast. The juxtaposition emphasises the textural, three-dimensional, and topographical qualities of the ulcers. The second image deploys colour to add diagnostic specificity to the sores. At the same time, the rust and maroon pigment seems to ripple and pool against the skin behind it, whose ochre fields undulate and appear almost abstract. As syphilis primarily presented visually on the surface of the skin, its study fell between the disciplines of dermatology and venereology, specialties often undertaken together in France around the turn of the century. ${ }^{2}$ Fournier's supreme focus on texture and colour in his illustrations, then, follows in a tradition of visual representation in dermatology that prioritised close attention to the details of eruptions on the surface of the skin to facilitate the detection, diagnosis, and treatment of disease. Historian Katherine Ott has termed dermatology the 'most visual of all medical subspecialties', where physicians looked 'first at the lesion, then at the rest of the skin, and then at the whole person'. 3 In France, scholars trace this visual tradition back to Jean-Louis Alibert and his early nineteenth-century atlases, which were lavishly illustrated with hand-drawn and handcoloured engravings. ${ }^{4}$ By Fournier's 1912 publication, however, photography and its claims to mechanical objectivity would seem to provide the logical tool and medium for accurately recording and reproducing the visible signposts of syphilis. Recent and significant scholarship on scientific and medical illustration, most notably Lorraine Daston and Peter Galison's formative Objectivity, would seem to support such a claim. ${ }^{5}$

\footnotetext{
${ }^{1}$ Edmond Fournier, Syphilis héréditaire de l'âge adulte (Paris: Masson et Cie, 1912), 19. All translations are my own unless otherwise noted.

${ }^{2}$ George Weisz, 'The Development of Medical Specializaton in Nineteenth-Century Paris', in A. La Berge and M. Feingold (eds), French Medical Culture in the Nineteenth Century (Amsterdam-Atlanta, GA: Radopi B. V., 1994), 166, 175. Given the close relationship between dermatology and venereology in the period under consideration, I will use the terms dermatology, venereology and dermatovenereology interchangeably.

${ }^{3}$ Katherine Ott, 'Contagion, Public Health, and the Visual Culture of Nineteenth-Century Skin', in David Serlin (ed.), Imagining Illness: Public Health and Visual Culture (Minneapolis, MN: University of Minnesota Press, 2010), 92.

${ }^{4}$ L.S. Jacyna, 'Pious Pathology: J.-L. Alibert's Iconography of Disease', in Caroline Hannaway and Ann La Berge (eds), Constructing Paris Medicine (Amsterdam: Editions Rodopi B. V., 1998), 185.

${ }^{5}$ Lorraine Daston and Peter Galison, Objectivity (New York, NY: Zone Books, 2007), 19-21.
} 


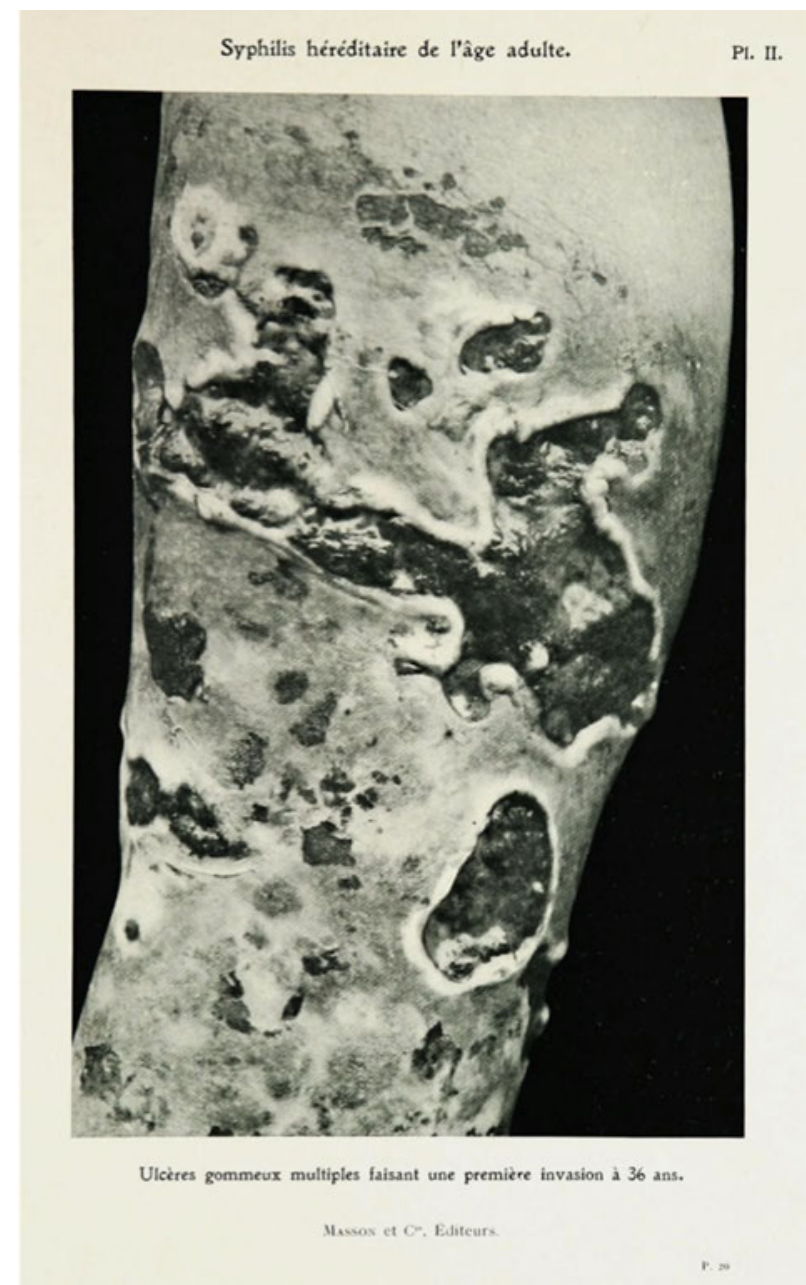

Figure 1: Alfred Fournier, Ulcères gommeux multiples faisant une première invasion à 36 ans, 1888, photograph, published in Edmond Fournier, Syphilis héréditaire de l'âge adulte, 1912. Source: gallica.bnf.fr/Bibliothèque Nationale de France.

A closer examination of dermatological and venereological educational materials, however, reveals that photography's relationship to the study of syphilis warrants further unpacking. Despite the documented rise of mechanical objectivity and concurrent efforts to eliminate subjective intervention in scientific image-making in the late nineteenth century, artist-produced, wax-cast, three-dimensional medical models, known as moulages, coexisted with photographs as significant educational tools in dermatovenereology from the 1860 s until at least the $1940 \mathrm{~s} .{ }^{6}$ Beyond the classroom, physicians often

\footnotetext{
6 Thomas Schnalke, Diseases in Wax: The History of the Medical Moulage, trans. Kathy Spatschek (Chicago: Quintessence, 1995), 13. Archival records indicate that the mouleur Stéphan Joseph Littre remained employed at the Saint-Louis hospital until 1965. See Directeur of the Administration Générale de l'Assistance Publique à Paris, 'Résiliation: Contrat de Littre', June 11, 1965, Cote: 826W27, Archives de l'Assistance Publique Hôpitaux de Paris, Paris.
} 


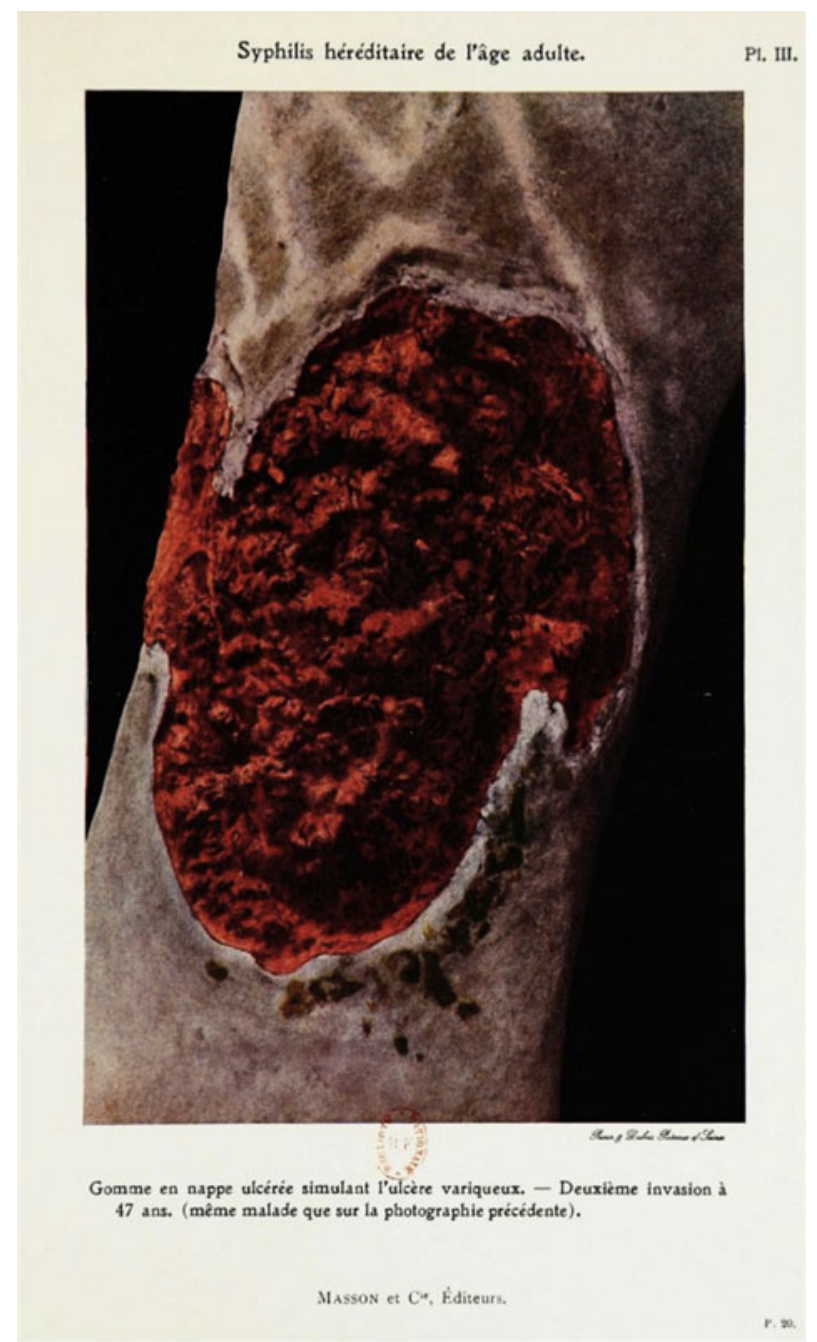

Figure 2: Alfred Fournier, Gomme en nappe ulcérée simulant l'ulcère variqueux. - Deuxième invasion à 47 ans, 1898, photograph, published in Edmond Fournier, Syphilis héréditaire de l'âge adulte, 1912. Source: gallica.bnf.fr/Bibliothèque Nationale de France.

cited photographs and moulages - both the objects themselves and lithographic and photographic reproductions of them in print - as equally valid kinds of proof in their written texts and treatises. Writing about moulages in particular, physicians simultaneously praised the wax models' lifelike qualities while also celebrating the craftsmanship demonstrated by moulage makers, or mouleurs, muddling any clear divide between subjective and objective image making. Many dermatological photographs similarly tangle the relationship between subjective and objective image production; while all photographs require the intervention of the artist's hand, many of the photographs produced by and for dermatologists were hand-painted after development to bring out the skin's colour and texture. Those destined for print publications, like Fournier's colour image cited above, 


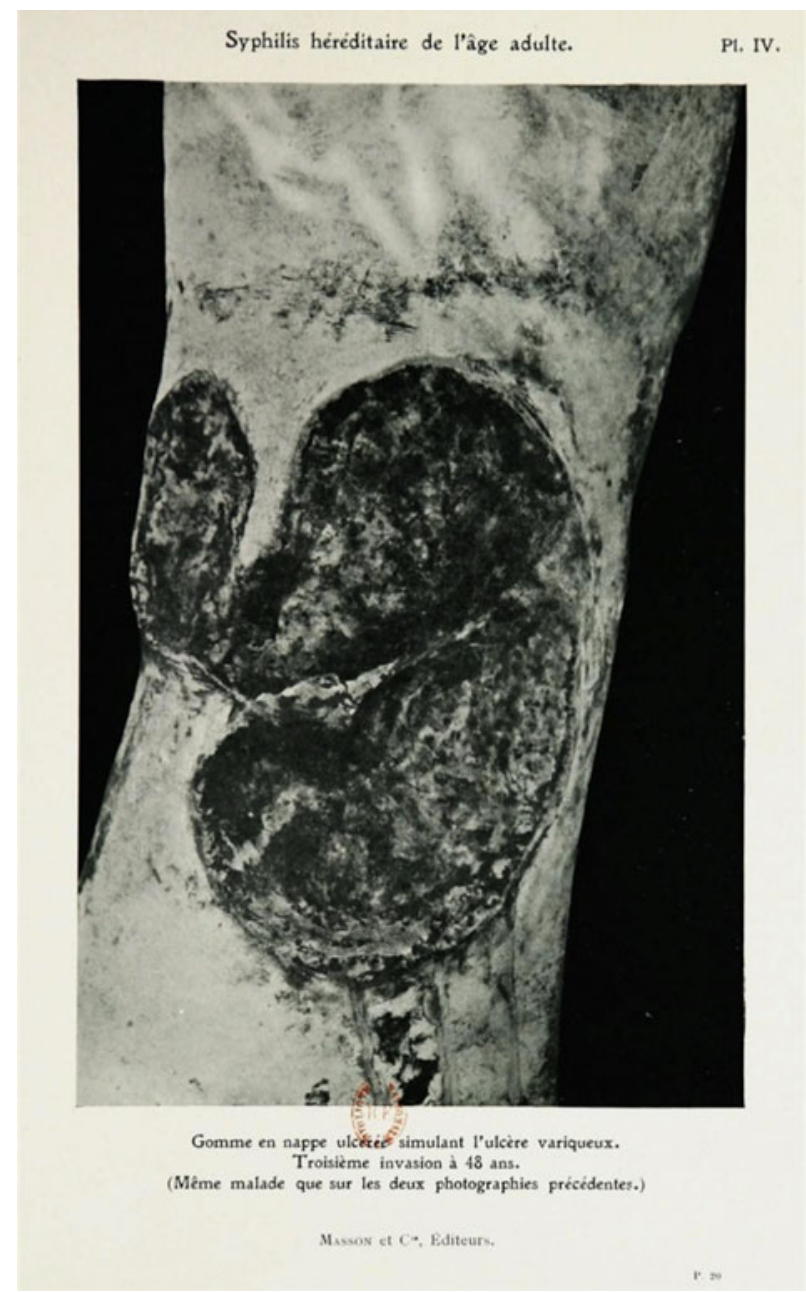

Figure 3: Alfred Fournier, Gomme en nappe ulcérée simulant l'ulcère variqueux. Troisième invasion à 48 ans, 1899, photograph, published in Edmond Fournier, Syphilis héréditaire de l'âge adulte, 1912. Source: gallica.bnf.fr/Bibliothèque Nationale de France.

would also require the artist to balance the influence of the three primary colours to achieve lifelike pigmentation and to hand-correct garish colours. ${ }^{7}$

This paper takes up fin-de-siècle French syphilography as a case study that complicates and expands our understanding of the material requirements, pedagogical goals, and representational strategies of late nineteenth- and early twentieth-century medical image making. While scholars have undertaken independent studies of moulages and dermatological photographs, less has been done to interrogate the relationship between the two. ${ }^{8}$ By attending to the nexus of these two media, I identify a larger visual strategy at

\footnotetext{
${ }^{7}$ Ernest Coustet, Traité général de photographie en noir et en couleurs, 6th edn (Paris: Delagrave, 1921), 360-3.

${ }^{8}$ For important writing on moulages, especially collections at the Saint-Louis hospital in Paris, see Mechthild Fend, "'Order and affect": the Museum of Dermatological Wax Moulages at the Hôpital Saint-Louis in Paris', in Johannes Grave, Christiane Holm, Valérie Kobi, and Caroline van Eck (eds), The Agency of Display: Objects, Framings, and Parerga (Dresden: Sandstein Verlag, 2018); Mary Hunter, “Effroyable Réalisme”: Wax,
} 
work across both dermatological photography and moulages. This mode of visualisation does not prioritise the elimination of subjective interference, nor traces of the expert hand in mediation - the method Daston and Galison term 'trained judgment' and identify with the second quarter of the twentieth century. ${ }^{9}$ Rather, I call attention to a visual strategy that privileges witness, that evinces direct observation of the pathological body represented, and that accessions a 'having-been-there' quality most closely linked with photography and famously theorised by Roland Barthes. ${ }^{10}$ In this way, the present essay builds on Martin Kemp's recognition that nineteenth-century medical photographers sought to establish a 'rhetoric of reality' in their images, and is in dialogue with Jennifer Tucker's Nature Exposed: Photography as Eyewitness in Victorian Science; while Tucker's study calls attention to the ways photographs acted as 'virtual witnesses' in British scientific illustration, I locate the contours of parallel representational priorities across multiple media - which is to say, beyond the bounds of photography - in fin-de-siècle French medical image-making. ${ }^{11}$ Through sustained visual analyses of the images deployed in dermatological education, close readings of medical treatises, and the identification of analogous materialities among the skin and the light-sensitive photographic plate, I articulate a nuanced, two-part understanding of objectivity vis-à-vis photography and syphilis that underpins this representational strategy. First, dermatologists did not marshal photography in their written theses because these images were unbiased or unmediated. As described above, moulages were fabricated by hand and dermatological photographs were rarely unaltered by the artist's hand. Rather, I posit that physicians deployed photography and the photographic to exploit the verbal and visual rhetoric of objectivity, authority and persuasion inextricably linked to culturally constructed understandings of the photograph. And second, that the rhetoric of the photograph and the photographic were often couched in the Peircean concept of indexicality. ${ }^{12}$

Femininity, and the Madness of Realist Fantasies', RACAR: Revue d'art Canadienne/Canadian Art Review 33, 1/2 (2008); Mary Hunter, The Face of Medicine: Visualising Medical Masculinities in Late Nineteenth-Century Paris (Manchester: University of Manchester Press, 2016), especially chapter 2, 'The sleep of reason: Dr Jules Émile Péan's collection of bodies in wax and in paint'; Thomas Schnalke, 'Casting skin: meanings for doctors, artists, and patients', in Soraya de Chadarevian and Nick Hopwood (eds), Models: The Third Dimension of Science (Stanford: Stanford University Press, 2004); Schnalke, Diseases in Wax; and Gérard Tilles and Daniel Wallach, Le musée des moulages de l'hôpital Saint-Louis (Paris: Doin Éditeurs, 1996). For scholarship on the photographic production centred at the Saint-Louis hospital, see Sophie Delpeux, 'Photographie en dermatologie à l'Hôpital Saint-Louis (1860-1900)' (Unpublished Masters Thesis, Université Paris 1 Panthéon-Sorbonne, 1998) and Gérard Tilles, 'Histoire des bibliothèques médicales et des musées des hôpitaux de l'assistance publique à Paris. L'exemple de l'hôpital Saint-Louis', (Doctoral Dissertation, Université Paris XII, 1995).

9 Daston and Galison, Objectivity, 19-21. It should be made clear that Lorraine Daston and Peter Galison's goal in Objectivity was never to give a detailed account of all models of scientific image making. Rather, they sought to identify larger trends in representation from the eighteenth through twentieth centuries, largely in Europe and North America, which they do with great success. I grapple with their text because it is the most recent and most comprehensive scholarly contribution to the field of scientific image making, but also because its broad scope encourages a wake of microhistories that nuance its claims, for, as the authors write, "some significant historical phenomena are invisible at the local level, even if their manifestations must by definition be located somewhere, sometime'. See Daston and Galison, Objectivity, 47.

${ }^{10}$ Roland Barthes and Stephen Heath, Image-Music-Text (New York, NY: Hill and Wang, 1978), 44.

11 Jennifer Tucker, Nature Exposed: Photography as Eyewitness in Victorian Science (Baltimore, MD: The Johns Hopkins University Press, 2005), 7; Martin Kemp, “A perfect and faithful record”: mind and body in medical photography before 1900', in Beauty of Another Order: Photography in Science, ed. Ann Thomas (New Haven, CT: Yale University Press, 1997), 123.

12 While I invoke Peirce's late nineteenth-century writings as historically situated texts, it should be noted that the role of the index in the broader history of photography and in art history has been consistently and hotly debated over the past fifty years. These dialogues largely center on the ontology of photography, that is, analyses 
For Charles Sanders Peirce, whose work in linguistics has become a cornerstone of semiotic theory, an index is a sign that 'refers to its object... because it is in dynamical (including spatial) connection both with the individual object, on the one hand, and with the senses of memory of the person for whom it serves as a sign, on the other hand. ... ${ }^{13}$ In Peirce's schema, the index has a direct relationship, one of physical contact, with the object it signifies. ${ }^{14}$ Notably, both photographs and moulages could be understood to rely on an indexical relationship between an object and its representation; in photography, light bounces off of the body and onto light-sensitive negatives, while the wet plaster of the moulage mould is formed around the tissue of the specimen. ${ }^{15}$ It is also worth noting that Peirce developed these ideas from the 1860 s into the early twentieth century and famously presented them at Harvard in 1903 - the same period under consideration in this paper. Peirce's invocation of 'the senses of memory' contained by the index also aligns with the function of photographs and moulages for turn-of-the-century dermatologists: they served as pedagogical tools and reminders of particular cases, frozen in time for repeated contemplation. I argue that as the threat of syphilis grew and physicians' vision became less reliable in diagnosis, the rhetoric of the photographic - particularly its ties to the historically situated idea of the index, which fin-de-siècle physicians formulated through the language of witness, testimony, and direct connection - came to comprise a critical tool for the substantiation of dermatovenereological theories.

\section{Visualising Syphilis at the Turn of the Century}

Integral to disentangling photography's mediation of syphilitic skin is an understanding of the dramatic changes in how French physicians saw, diagnosed, and understood syphilis in the first decade of the twentieth century. In 1899, the year Fournier's final photograph was taken, the specific causal agent of syphilis remained unknown. Anxiety surrounding syphilis's contribution to degeneration and depopulation grew in the wake of France's devastating 1871 defeat in the Franco-Prussian War, gaining traction during the last third of the nineteenth century and peaking in the early years of the twentieth century. A 1903 statement drafted and presented to the Academy of Medicine by Alfred Fournier demonstrates the threat syphilis constituted in the eyes of fin-de-siècle physicians:

A danger permanently menaces public health. This danger resides in the disease that one could call the modern plague and which is none other than syphilis. This danger is serious, very serious. Syphilis, in effect, is not ... like other diseases... it's something else entirely. It's a stable, permanent infection that is extra-fertile in every manifestation. ${ }^{16}$

of its status as a mechanical reproduction of the world. See Rosalind Krauss, 'Notes on the Index: Seventies Art in America, Part 1', October, 1977; Rosalind Krauss, 'Notes on the Index: Seventies Art in America, Part 2', October, 1977; Susan Sontag, On Photography (New York: Farrar, Straus and Giroux, 1977); and Michael Leja, 'Peirce, Visuality, and Art', Representations, 2000.

${ }^{13}$ Charles S. Peirce, 'Logic as Semiotic: The Theory of Signs', in Robert E. Innis (ed.), Semiotics: An Introductory Anthology (Bloomington, IN: Indiana University Press, 1985), 12-3.

${ }^{14}$ Leja, 'Peirce, Visuality, and Art', 101; Albert Atkin, 'Peirce on the Index and Indexical Reference', Transactions of the Charles S. Peirce Society 41, 1 (2005), 178.

${ }^{15}$ In fact, Peirce identifies the photograph as a quintessential example of the index, stating, 'Photographs ... are very instructive, because we know that they are in certain respects exactly like the objects they represent. But this resemblance is due to the photographs having been produced under such circumstances that they were physically forced to correspond point by point to nature'. See Peirce, op. cit. (note 13), 11.

16 Alfred Fournier, Prophylaxie de la syphilis (Paris: J. Rueff, 1903), 2. 
Fournier's description places the peril of syphilis beyond the comprehensible bounds of early twentieth-century medical science. It comprises a 'modern plague' perpetually threatening to infiltrate and devastate not only individuals, but also their families and the entire French race. ${ }^{17}$

Syphilis's volatile relationship to vision amplified this threat. Unlike other dermatological conditions, the typical progression of syphilitic infection - three stages of highly visible rashes interrupted by somewhat unpredictable periods of remission - resulted in a marked degree of visual, and thus diagnostic and therapeutic, uncertainty. When signs did appear, they mimicked those of other illnesses, earning syphilis the moniker 'the great imitator'. ${ }^{18}$ Close readings of medical treatises reveal that anxieties about syphilitic symptoms' legibility pervaded writing about the disease. Alfred Fournier's fifth law of syphilis's clinical progression provides a representative example: 'The primary accident', he recounts:

gives way to an explosion of other multiple and varied symptoms. . . Whatever they may be, these new accidents all share a common characteristic; all of them are essentially different from the primary accident. ... The whole body seems to be their domain, and their multiplicity is only equaled by their infinite variety of forms and expressions. ${ }^{19}$

Similarly, in his 1886 La Syphilis héréditaire tardive [Late Hereditary Syphilis], Fournier used the term masque (as either a noun, verb or its derivative adjective, masqué), thirteen times. The word frequently described how syphilis almost eluded the diagnostic eye: syphilis can 'borrow the mask of other lesions' to evade the diagnostician, or cause the face to appear 'as if covered by a dark, crusty, fissured mask'. ${ }^{20}$ As Fournier's accounts demonstrate, and as I argue in greater depth elsewhere, syphilis's 'infinite variety' of symptoms came to constitute a problem of visual certainty for fin-de-siècle physicians, a source of anxiety stemming from signs unmoored from clear meaning. ${ }^{21}$ Subsequently, dermatological education prioritised honing medical students' visual acuity. Rigorous training in the visible signs of syphilitic irritations versus tubercular or gonorrhoeal rashes, for example, comprised an integral component of dermatovenereological education, requiring years of clinical experience coupled with the study of images circulating in atlases and held in hospital museum collections.

More disconcerting than acquired syphilis, however, was the subject of Edmond Fournier's text: hereditary syphilis. In addition to the detrimental effects of acquired syphilis, this insidious and pervasive congenital disease, believed to be passed down imperceptibly from generation to generation, could cause deafness, dental deformations, respiratory symptoms, circulatory symptoms, epilepsy, and other neurological conditions. ${ }^{22}$ Hereditary syphilis's potential to remain dormant until adulthood, or to skip a generation and appear in the grandchild of a syphilitic, proved to be most troubling of all; an

\footnotetext{
${ }^{17}$ Alfred Fournier, 'But et espérances de notre société', Bulletin mensuel de la Société française de prophylaxie sanitaire et morale, 1, 1 (1901), 5.

${ }^{18}$ Rebecca J. Culyba, 'Classification and the Social Construction of Disease in Medical Systems: A Historical Comparison of Syphilis and HIV/AIDS in the United States' (Dissertation, Northwestern University, 2008), 10.

${ }^{19}$ Alfred Fournier, Leçons sur la syphilis: étudiée plus particulièrement chez la femme (Paris: A. Delahaye, 1873), 19-20. Emphasis my own.

${ }^{20}$ Alfred Fournier, La Syphilis héréditaire tardive (Paris: G. Masson, 1886), 340, 620-1.

${ }^{21}$ Kathleen Pierce, 'Surface Tension: Skin, Disease, and Visuality in Third Republic France' (Dissertation, Rutgers University, 2019), 17, 20-5.

22 Claude Quétel, History of Syphilis, trans. Brian Pike and Judith Braddock (Baltimore, MD: Johns Hopkins University Press, 1992), 166-8.
} 
infection's hereditary menace permanently threatened a patient's family's future welfare. The general public shared physicians' concerns. As historian Martha Hildreth relates, 'A doctor's diagnosis of one of the dreaded hereditary diseases coloured how the family thought about its past, planned for its future, and how it was perceived by the community. ${ }^{23}$ As with acquired syphilis, medical vision was at the crux of this menace; hereditary syphilis left even fewer discernible traces and could pass unnoticed down the family line.

In 1905, German scientists Erich Hoffman and Fritz Schaudinn isolated Treponema pallidum, the syphilis microbe. ${ }^{24}$ In 1906, German bacteriologist August Paul von Wassermann, along with Albert Neisser and Carl Bruck, developed a complement fixation reaction test whose sensitivity to certain antibodies in a patient's blood indicated the presence or absence of a syphilitic infection. ${ }^{25}$ The Wassermann test, therefore, excised historically requisite models of medical vision from the act of diagnosis. For the first time, a person who failed to exhibit symptoms - as was common for patients in the period of remission between the second and third stages of the disease - could be identified as carriers. Invisible illness could be revealed. Yet the Wassermann test was far from infallible. It was known to result in false positives, further exacerbating emerging tensions between vision and diagnosis, image and education. ${ }^{26}$ This amplified visual ambiguity, I argue, made the indexical qualities of both photographs and moulages all the more seductive.

\section{Representing Diseased Skin}

It is in this climate of anxiety surrounding the observation and detection of syphilis that Edmond Fournier published his father's photographs. Photography's central role in Fournier's text meshes with the larger shift from drawings or engravings produced within the 'truth to nature' framework to mechanically produced images that Daston and Galison identify in scientific image making. ${ }^{27}$ This shift, they posit, is largely due to scientists' growing self-conscious concerns about their potential subjective influence, apprehensions that peaked in the second half of the nineteenth century. ${ }^{28}$ Associations between photography and truth, however, were not limited to the sphere of science. As Andrés Zervigón and Sabine Kriebel have recently argued, nineteenth-century conceptions of the photograph as 'absolute truth', 'exact and rapid', and representative of 'the real' have been tacked onto - and remained with - photography in the West from its inception. ${ }^{29}$ At the same time, nineteenth-century audiences also understood that the photograph could be staged, altered, or edited: in short, that photography could lie. Yet as Zervigón and Kriebel argue, repeated metaphoric theorisations of the indexical relationship between the photograph and referent - where photography was the 'pencil of nature' or the photograph became the 'mirror with a memory' - coupled with the mechanical technology of the

\footnotetext{
${ }^{23}$ Martha L. Hildreth, 'Doctors and Families in France, 1880-1930: The Cultural Reconstruction of Medicine', in A. La Berge and M. Feingold (eds), French Medical Culture in the Nineteenth Century (Amsterdam-Atlanta, GA: Radopi B. V., 1994), 191.

${ }^{24}$ Quétel, History of Syphilis, 140.

25 Ibid., 141 .

26 Ibid..

27 Daston and Galison, Objectivity, 20.

28 Ibid., 120.

${ }^{29}$ Edgar Allen Poe and Dominique François Arago qtd. in Sabine T. Kriebel and Andrés Mario Zervigón, 'Introduction', in Sabine T. Kriebel and Andrés Mario Zervigón (eds), Photography and Doubt (New York: Routledge, 2016), 1.
} 
camera 'rendered the medium intelligible and, in turn, made its testimonial force possible in the face of continual limitations and doubts' ${ }^{30}$ In this way, photographs and the verbal and visual rhetoric of the photographic continued to harness connotations of truthfulness and authority through the turn of the century.

In many ways, the production of medical moulages comprised photography's inverse. In opposition to photography's dizzying rate of technological change, moulages were produced at the Saint-Louis hospital in Paris - an international centre of dermatovenereological research and image production - in much the same way from the 1860 s to the 1940 s. They began as plaster casts of the part of the live body physicians sought to reproduce. Recent laboratory studies of the work of Baretta, the first Parisian mouleur, reveal that he used a mixture of bee's wax and resin that he heated to 200 degrees Celsius before transferring to the plaster cast. A base flesh-tone may have been added to this heated mixture, although the mouleur added the majority of colour and final details - such as body hair or glass eyes - by hand, after the casting process. This included not only using paint to achieve a chromatic likeness to various symptoms, but also exploiting the malleability of wax to achieve a great variety of surface textures, from the glossy, soft, and almost wet finish of chancres to the smooth borders of hard indurations. Finally, the finished models were mounted on solid black wooden boards; numbered, labelled, and grouped by ailment; and hung alongside hundreds of other moulages behind glass in the hospital museum. ${ }^{31}$ Moulages were thus centrally available for study by medical students and physicians, as well as by attendees of major dermatological conferences which were often held in the hospital museum. Where photographs were mechanically produced at rapid rates, handcrafted moulages took hours of work to create. Yet as we will see, physicians consistently praised moulages for their ability to exactly match the patient they depicted.

Several scholars have explored the relationship among moulages, photography and objectivity. Thomas Schnalke pits moulages in competition against photography, locating colour as the hinge of their opposition. As reliable colour photographs could not be printed until the mid-twentieth century, Schnalke contends, moulages rose to prominence. ${ }^{32}$ Yet I would argue that the relationship between moulages and photographs was far less divisive than Schnalke describes, evinced primarily by physicians' frequent reliance on both photographs and moulages as visual evidence, but also demonstrated by the ways authors metaphorically describe both media as indexical.

While it is not the main focus of her paper, Mary Hunter also attends to the indexicality of medical moulages in her compelling analysis of Dr Jules Péan's moulages and the relationship between gender, wax, and collecting. Hunter identifies moulages as indexical objects that annex claims to truth and reason through the medium of wax, which closely mimics the look of bodily surfaces. ${ }^{33}$ She contends that the "models were understood by contemporary viewers as realistic objects that depicted the visible world accurately and with the utmost objectivity'. ${ }^{34}$ While I agree with Hunter's assertion that moulages were understood, in some ways, as indexical objects, I argue that the relationship between moulages and indexicality, and therefore moulages and objectivity, is at once more

\footnotetext{
${ }^{30}$ Kriebel and Zervigón, 'Introduction', 2.

31 Schnalke, Diseases in Wax, 9-11.

32 Schnalke, Diseases in Wax, 13; Schnalke, 'Casting Skin', 216-7.

${ }^{33}$ Hunter, 'Effroyable Réalisme', 51.

${ }^{34}$ Ibid., 43.
} 
complicated and revealing than she describes. Unlike traditional understandings of the referent and index - like fire and smoke - where the index is a direct, unmediated trace, moulages have necessarily undergone additional transformations at the hands of mouleurs. Arguably, the most significant portion of the dermatological moulage - its surface layer depicting symptoms' colours and textures - was almost all hand-finished after the moulage was removed from its mould. Physicians also complicate this relationship in their writings. They do describe moulages as perfect and exact representations of their patients. Yet they also celebrate the work of mouleurs such as Baretta, simultaneously calling attention to the subjective fabrication of moulages and to the skill and craftsmanship required to produce them. $^{35}$

Most recently, in her study of the Saint-Louis moulages and affect, Mechthild Fend very briefly addresses the wax casts' relationship to photography and objectivity, writing that the moulages 'ranked equal with photography' and that the value of both was 'seen in their quality as imprints'. ${ }^{36}$ In Fend's view, however, moulages' truth-telling potential surpassed that of photographs because of their three-dimensionality, scale (as life-size reproductions), and the use of colour. ${ }^{37}$ Fend's identification of the 'imprint' meshes with historical conceptions of the index excavated throughout the present essay, although she does not explore the relationship between the 'imprint' and the index or historical conceptions of the index. Furthermore, despite initially identifying photographs and moulages as 'equal', she ultimately asserts a kind of hierarchical divide, in a mode reminiscent of Schnalke, among photographs and moulages, where moulages were preferred for their accurate reproductions of colour. Indeed, some nineteenth-century writers asserted just such an opinion; in the introduction to an illustrated atlas issued by the Saint-Louis moulage museum, the physician and museum's administrator Henri Feulard, for example, wrote that other modes of image production 'were inferior' to moulages, given the latter's colouration in concert with their three-dimensional qualities. ${ }^{38}$ Yet close looking at the ways physicians deployed visual representations of dermatological disease reveals that this hierarchy did not hold in practice and did not necessarily govern which kinds images physicians cited in their research and pedagogy. While I do not want to downplay the significant ways that medium helps construct meaning in representation (both within and without the sphere of medicine), I posit that the relationship between dermatological photographs and moulages was at once more reciprocal and muddled than scholarship has previously recognised.

\section{Visual Evidence and the Index}

Dermatovenereologists frequently demonstrate the complicated relationship between moulages, photography, indexicality, and objectivity when invoking both kinds of images in their writing. Take, for example, the Saint-Louis museum's atlas described above, the 1895 Musée de l'Hôpital Saint Louis: Iconographie des maladies cutanées et syphilitiques [Museum of the Saint-Louis Hospital: Iconography of Skin Disease and Syphilis], in whose introduction Feulard declared moulages to be superior to other kinds of medical images. The atlases' authors framed the text as a celebration of the museum's wax collections,

\footnotetext{
${ }^{35}$ Henri Hallopeau and Charles Fouquet, Traité de la syphilis (Paris: J.-B. Baillière et fils, 1911), v.

36 Fend, 'Order and Affect', 84-5.

37 Ibid., 85.

${ }^{38}$ Henri Feulard, 'Le Musée de l'hôpital Saint-Louis', in Ernest Besnier and Alfred Fournier et al., Le Musée de l'Hôpital Saint Louis: Iconographie des maladies cutanées et syphilitiques (Paris: Reuff et cie., 1895).
} 
which deserved a broader audience of the kind the atlases' mobility and reproducibility afforded. The authors' ability to visually circulate their collections, however, was only made possible through the photographic reproduction of their moulages in a mode that the physicians referred to as 'photochromie'. ${ }^{39}$ These twice-mediated illustrations of patients - first through wax casting and again through photography - allowed readers to see 'very exact' reproductions of symptoms and visually diagnose patients 'straightaway' with 'a simple glance of the eye' - as if, it would seem, the viewer stood before the patients themselves. ${ }^{40}$ Yet, describing a case study encapsulated in one of the casts, Dr Lucien Jacquet lamented that the photographic reproduction of the moulage, as well as the moulage itself, insufficiently demonstrated the scale of the represented dermatological growth. Among the medium's flaws, Jacquet contends, is a marked shrinkage from the patient's body to the final model, a problem inherent to the casting process. To correct this representational issue, Jacquet supplied a photograph of the patient herself as a visual corrective. ${ }^{41}$ In the case of the Saint-Louis atlas, then, moulages, photographic reproductions of moulages, and photographs of patients work in concert with one another to construct medical truth.

Physicians demonstrate a similarly entangled relationship among moulages, photography, and indexicality in their treatises, particularly in the ways that they cite images as evidence. In the 1912 text with which I began this study, for example, Fournier argues that the development of rheumatism at a young age constitutes a symptom of hereditary syphilis. He first quotes the case study ('observation') of his mentor, Professor Gaucher, who writes that his recognition of the concurrence of tertiary syphilitic ulcers and rheumatism 'testifies to the intimate connection' between these two symptoms. ${ }^{42}$ In the next paragraph, Fournier writes that a 'photograph from his father's collection is no less instructive' than Gaucher's first-hand account. ${ }^{43}$ Fournier seems to equate the value of photographs and first-hand descriptions as evidence. In another section of the text, Fournier identifies facial asymmetry as a telling symptom and points to a 'photograph made in order to make an exact account [un compte exact] of this particularity'; a few sentences later, he discusses ways the disease can ravage the teeth and offers additional demonstrative support, particularly 'a moulage of Dr Chompret's' that 'shows it very well'. ${ }^{44}$ Within the same paragraph, Fournier cites both photographs and moulages as exemplary visual evidence. Alfred Fournier exhibits a similar double reliance on photography and moulages in an 1873 text where he proposes the distinction of a new type of follicular lesion. To substantiate his argument, he writes: 'See at the museum of the Lourcine [hospital for women] many moulages, drawings, or photographs, which realise exactly this lesion.... ${ }^{45}$ Fournier's grammar positions moulages, drawings, and photographs as synonymous in terms of their potential evidentiary status.

\footnotetext{
${ }^{39}$ Besnier, Fournier, et al., Le Musée de l'Hôpital Saint Louis, 1.

40 Ibid., 163, 53.

${ }^{41}$ Besnier, Fournier, et al., Le Musée de l'Hôpital Saint Louis, 192. It should be noted that this specific case study does not discuss an iteration of syphilitic infection, but rather describes a case of epithelioma following lupus. I reproduce it here, however, given the ways Jacquet's description of moulages and photographs meaningfully complicates the hierarchies among media established in other scholarship.

${ }^{42}$ Fournier, Syphilis héréditaire de l'âge adulte, 127; Gaucher qtd. in Fournier, Syphilis héréditaire de l'âge adulte, 127.

${ }^{43}$ Fournier, Syphilis héréditaire de l'âge adulte, 127.

${ }^{44}$ Ibid., 283. Emphasis my own.

${ }^{45}$ Fournier, Leçons sur la syphilis, 547. Emphasis my own.
} 


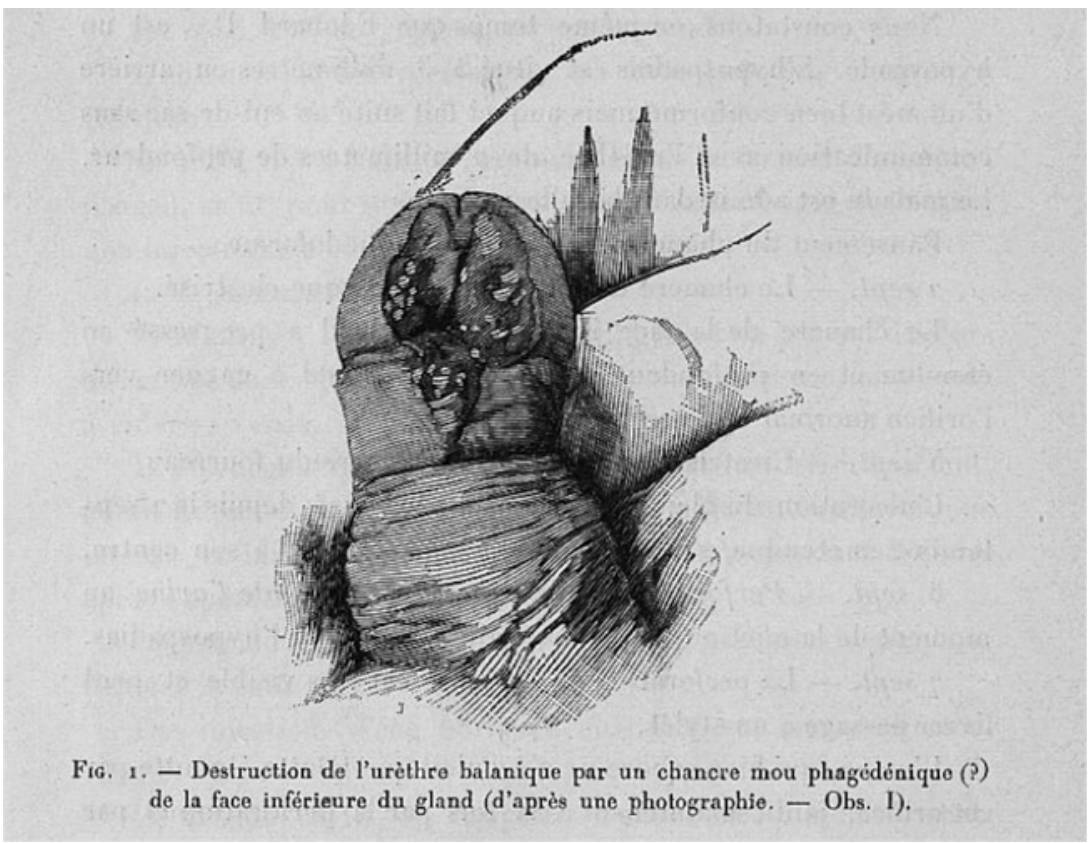

Figure 4: Fig. 1, ca. 1898, print after photograph, published in André Saint-Hilaire, Fistules uréthro-péniennes, 1898. Source: gallica.bnf.fr/Bibliothèque Nationale de France.

Similarly, on the frontispiece of his 1898 Fistules Uréthro-Péniennes [Urethro-Penile Fistulas], Dr André Saint-Hilaire advertises that his text includes fifteen figures, of which five were made after photographs and seven were made after moulages. ${ }^{46}$ Despite the emphasis he places on one figure's status as 'a very exact reproduction of a photograph that we possess', Saint-Hilaire seems to assess photographs and moulages as equally valid representations of a certain kind of evidence. ${ }^{47}$ Indeed, those figures made after photographs, such as the 'exact reproduction' cited above (Figure 4), appear in the same style as those made after moulages (Figure 5), wherein the light and shade composing each image have been reduced to precise hatch marks. Their visual parallels erase their originary media, which can only be discerned from the captions accompanying each image. Where Alfred Fournier offered a syntactical equation of photographs and moulages, SaintHilaire presents a visual example of the same phenomenon. Furthermore, Alfred Fournier, Edmond Fournier, and Saint-Hilaire all employ the term exact - diction suggestive of late nineteenth-century understandings of the photographic. ${ }^{48}$

\footnotetext{
46 André Saint-Hilaire, Fistules uréthro-péniennes consécutives au chancre simple et à la syphilis (Paris: G. Carré et C. Naud, 1898), np.

47 Ibid., 25.

${ }^{48}$ In French writing, the term 'exact' has been tied to photography and qualities of the photographic from the medium's origins. In the earliest known description of the process written by Louis Daguerre himself, a unique broadside almost certainly printed before 1839 and given to the George Eastman House collections, Daguerre writes that his early experiments following the death of Joseph Nicéphore Niépce were not entirely successful, as they 'did not record with enough exactness [exactitude]'. Describing the more satisfactory process revealed to the public in 1839 , he wrote, '[F]or art can imitate neither the exactness [exactitude] of the [daguerreotype] pictures nor their perfect detail...' In a report included in Daguerre's Historique et description des procédés
} 


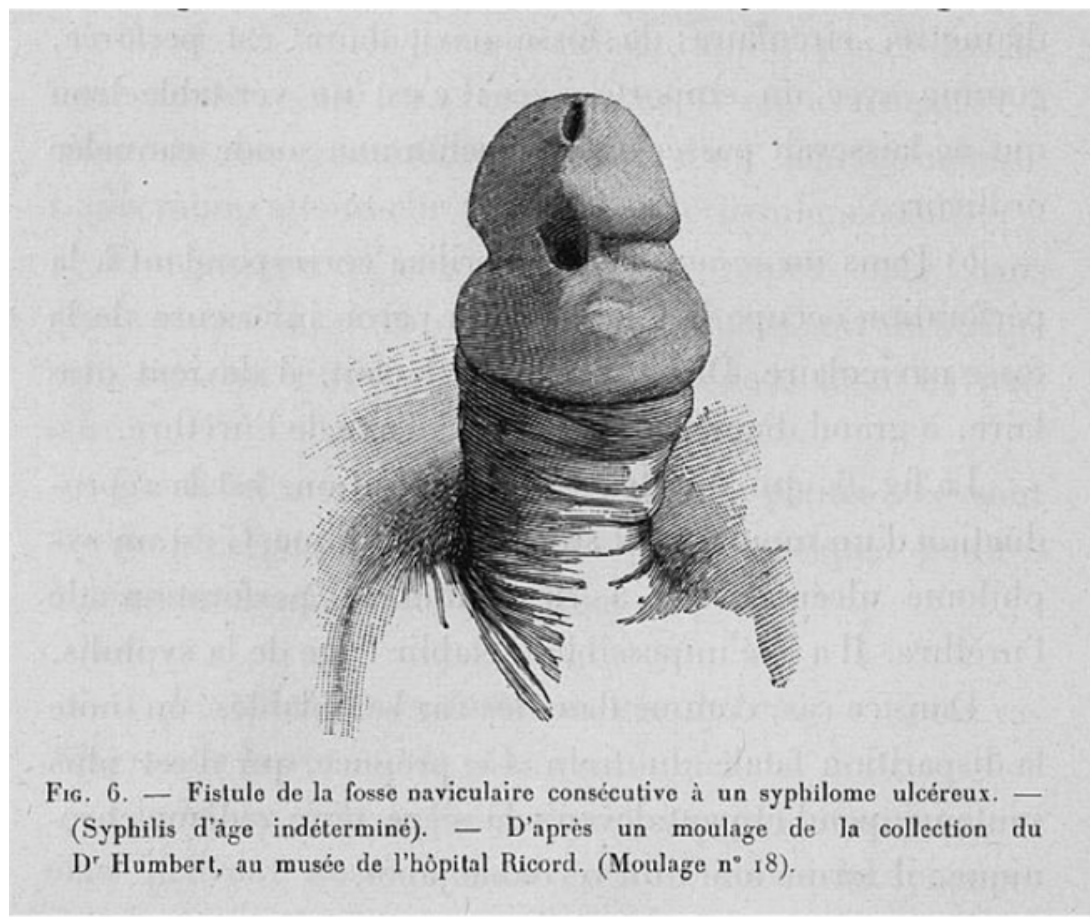

Figure 5: Fig. 6, ca. 1898, print after moulage, published in André Saint-Hilaire, Fistules uréthro-péniennes, 1898. Source: gallica.bnf.fr/Bibliothèque Nationale de France.

The aptly named Dr Hallopeau and his Saint-Louis colleague Dr Leredde offer yet another example of this phenomenon in their Traité pratique de dermatologie [Practical Treatise of Dermatology], published in 1900. In their argument for the distinction of a certain type of pemphigus, they state, 'our moulages, our photographs, and our descriptions bear witness'. ${ }^{49}$ Like Alfred Fournier, Hallopeau and Leredde syntactically liken moulages, photographs, and first-hand accounts. They describe all three as significant because they 'bear witness' or give testimony - qualities at the heart of the indexical sign. Yet Hallopeau and Leredde further complicate the relationship between photography and moulages by reproducing photographic representations of Saint-Louis moulages as visual evidence throughout their treatise. Unlike Fournier's trichrome image or the photochromies included in the Saint-Louis atlas, however, the physicians describe these photographs as aquarelles photographiques, or photographic watercolours, calling

$d u$ daguerreotype et du diorama [History and description of the processes of the daguerreotype and the diorama] of 1839, one M. Gay-Lussac similarly wrote, 'The principal advantage of the process of M. Daguerre consists of promptly obtaining - in a very exact [exacte] manner - objects' images....' An entry in an early twentieth-century edition of Le Larousse pour tous demonstrates the continuity of this connection; under the entry for 'photographier', or, to photograph, the reader finds among the definitions: 'To describe, to depict with a rigorous exactitude [exactitude]'. See Louis Daguerre, 'Daguerréotype', reproduced in 'An Announcement by Daguerre', Image: The Journal of the George Eastman House of Photography 8, 1 (March 1959), 33-6, translation from the French included in secondary source; Louis Daguerre, Historique et description des procédés du daguerreotype et du diorama (Paris: Alphonse Giroux et Cie, 1839), 34; and Pierre Larousse, Larousse pour tous: nouveau dictionnaire encyclopédique, Vol. 2 (Paris: Librairie Larousse, 1907-10), 435.

${ }^{49}$ Henri Hallopeau and Laurent-Victor-Louis-Emile Leredde, Traité pratique de dermatologie (Paris: J.-B. Baillière et fils, 1900), 734. 
attention to their subjective production through their terminology. These images were produced by the independent, professional photographer Félix Méheux, who owned a photography studio on the rue Lhomond in Paris and photographed Saint-Louis hospital patients for twenty years between 1884 and $1904 .{ }^{50}$ Méheux produced albumen prints that he finished with watercolours to 're-establish the colours in their finest details' ${ }^{51}$

Syphilides papulo-tuberculeuses [Papular-Tubercular Syphilids], a photographic watercolour Hallopeau and Leredde reproduce, typifies Méheux's work (Figure 6). Like Fournier's photographs and moulages themselves, the photographically rendered moulage floats on a solid black ground. The saturated colours of the patient's doubly mediated skin and papules pop against their white cloth frame. Yet a close examination of the photograph reveals the artist's hand. For example, light ochre pigment bleeds beyond the borders of the face on the forehead, the brow, and the bridge of the patient's nose. A comparison with the original moulage suggests additional variations (Figure 7). Although the deeper saturation of the colours in the photographic watercolour may be due to the moulage's more frequent exposure to light and, therefore, fading, the photograph elides a multitude of other details, such as the significant swelling beneath the papules of the forehead, smaller wrinkles and areas of swelling throughout the face, and the accurate placement of the papules on the topography of the face. Thus, it could be argued that in the case of his photographic watercolours, Méheux did not prioritise the exactness prized by the preceding authors. Considering his heavy intervention on the photographic surface, contemporary viewers may question in what ways, if at all, this image remains photographic. In fact, Méheux's process - the production of an indexical base image, a photograph, whose surface he hand finishes by building up layers of pigment to naturalistically describe the colour and texture of diseased skin - directly parallels moulage making. Yet the authors continue to refer to the image as photographique and to praise Méheux for his precise reproductions, describing the artist's hand as 'skilled and faithful'. ${ }^{52}$ In fact, Méheux's work was so well known that American dermatologist William Thomas Corlett travelled to Paris to solicit his services for a publication. Corlett recorded in his preface that he 'secured the services of Félix Méheux ... to colour the photographs', for he valued the 'truthfulness in detail of photographic reproductions' ${ }^{53}$ For turn-of-the-century dermatologists, then, photographic truthfulness points not to a direct copy or an unmediated illustration, but rather to a guarantee that the physician or artist who made the image had, in fact, observed this patient or example first-hand.

The changes that take place between two texts produced twenty years apart by Louis Brocq may serve to further resolve some of the complexities drawn out by Méheux's double mediation of syphilitic skin. Brocq, Ernest Besnier, and Lucien Jacquet published La Pratique dermatologique [Practical Dermatology] in four volumes between 1900 and 1904. On the frontispiece of each volume, the authors boast of the 823 figures in black and white and eighty-nine in colour featured across the full set. Echoing Ott's observation, the inclusion of images here remains of preeminent importance. While many of the illustrations demonstrate compositional and textural priorities similar to Fournier's

\footnotetext{
${ }^{50}$ Delpeux, 'Photographie en dermatologie à l'Hôpital Saint-Louis (1860-1900)', 26; 'Félix Méheux', cote: 826W507, Archives de l'Assistance Publique - Hôpitaux de Paris, Paris.

${ }^{51}$ Gérard Tilles and Daniel Wallach, 'Photographies dermatologiques au XIXe siècle', Annales de Dermatologie et de Venereologie, 125, 9 (September 1998), 647.

${ }^{52}$ Hallopeau and Leredde, Traité pratique de dermatologie, vi.

53 Corlett qtd. in Paula Summerly, 'Photographing Dermatology: The Collections of Dr William Thomas Corlett (1854-1948)', International Journal of Dermatology 47, 9 (2008), 967.
} 


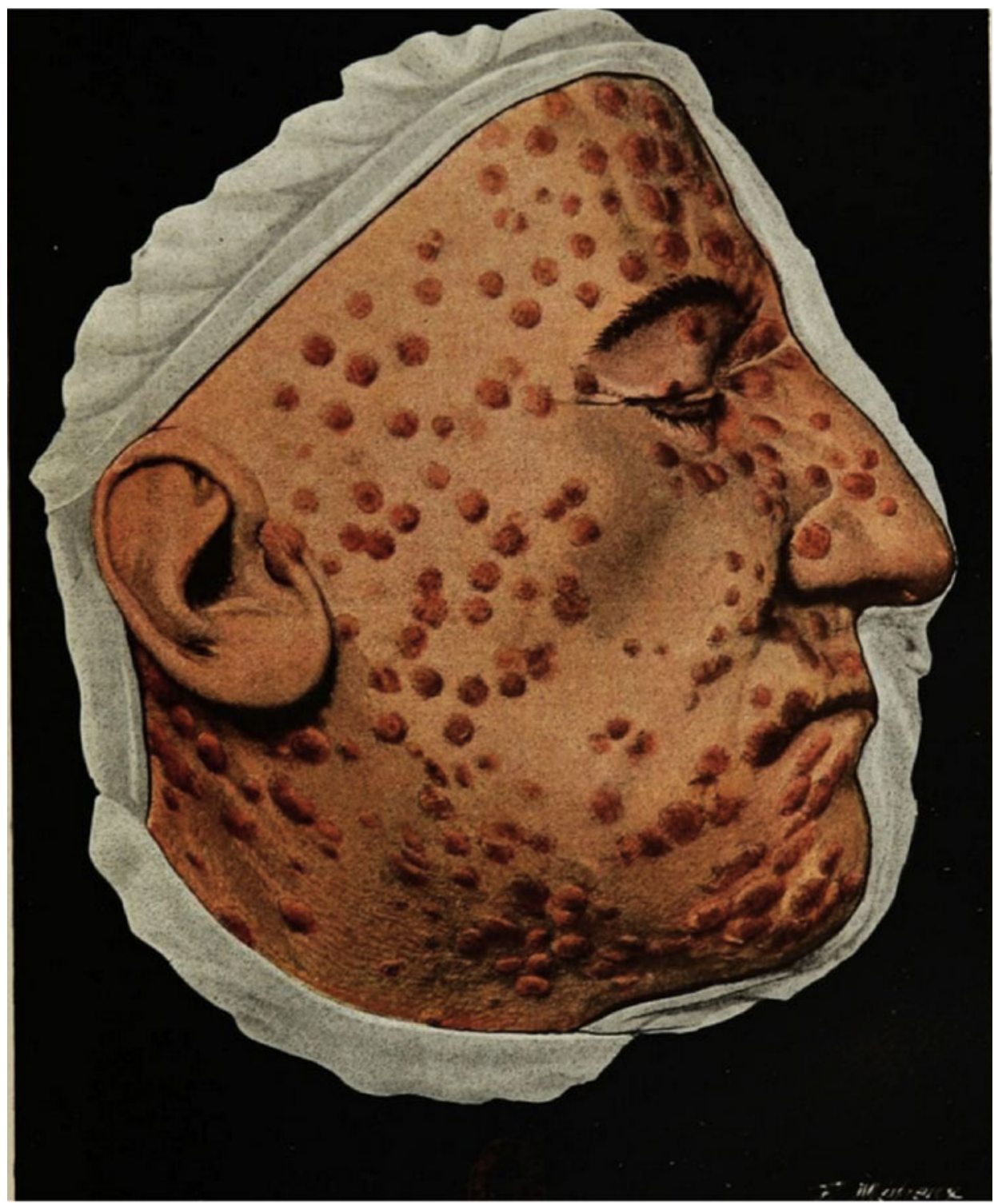

Figure 6: Félix Méheux, Syphilides papulo-tuberculeuses, 1900, photographic watercolour, published in Henri Hallopeau and Laurent-Victor-Louis-Emile Leredde, Traité pratique de dermatologie, 1900. Source: gallica.bnf.fr/Bibliothèque Nationale de France.

photographs, they are described as 'drawings' made 'as exact as one could currently [actuellement] do so'.54 The specific use of the word actuellement, linked as it is with news, les actualités, and the current, to modify the exactness of a reproduction doubly invokes photographic technology and the authors' desire to frame their illustrations as

${ }^{54}$ Ernest Besnier, Louis Brocq, and Lucien Jacquet, La pratique dermatologique: traité de dermatologie appliquée, Vol. 1 (Paris: Masson et Cie, 1900), iv. 


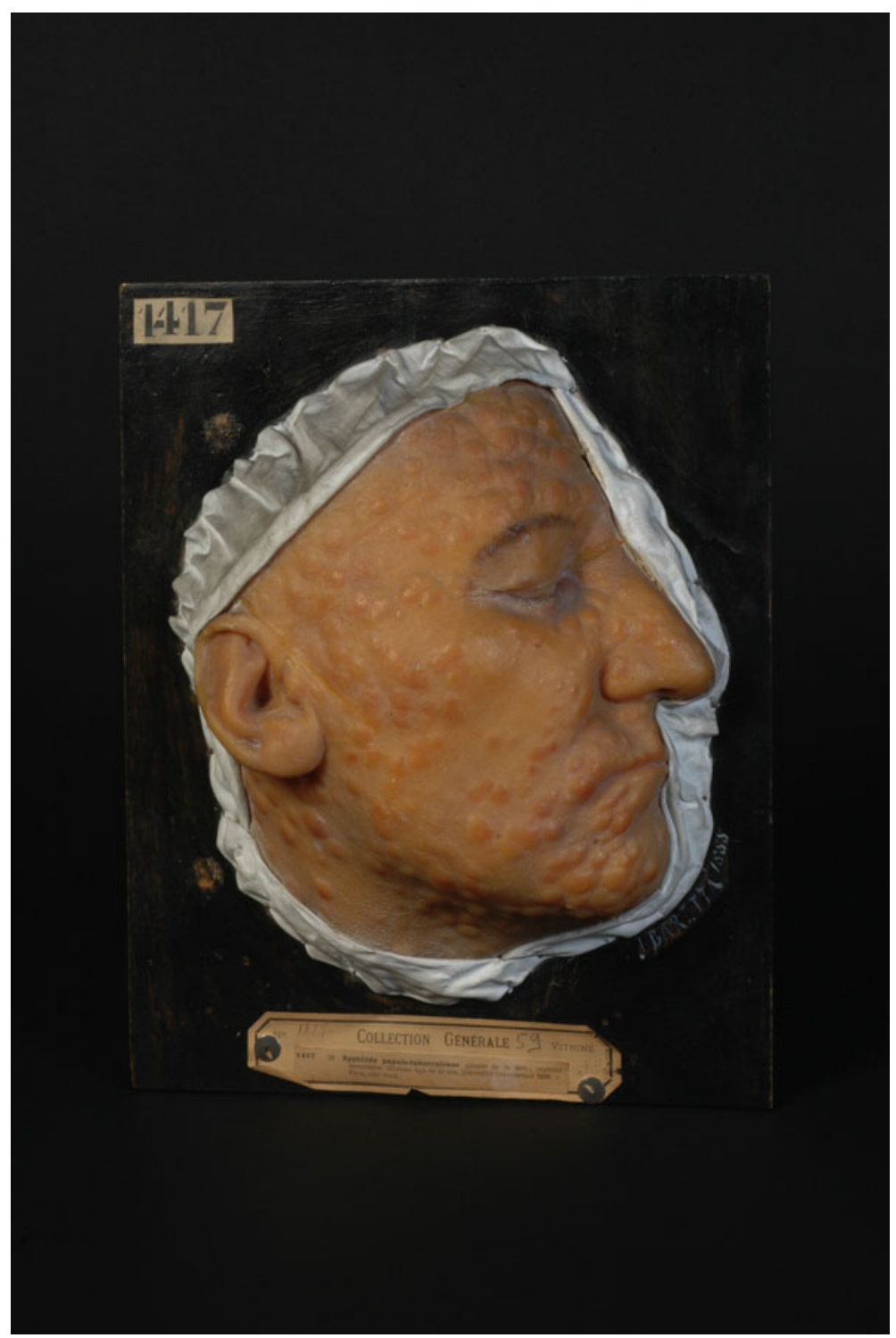

Figure 7: Jules Baretta, Syphilide papulo-tuberculeuse géante de la face; syphilis secondaire; homme âgé de 40 ans, journalier, 1888, wax moulage, Musée des Moulages, hôpital Saint-Louis, Paris. (c) F. Marin, P. Simon/Musée des moulages, Hôpital Saint-Louis, AP-HP.

analogues to photographic images made with the same rigor of naturalism. Yet, for perhaps a multiplicity of reasons - cost, convenience, the unique contents of a specific, nonphotographic visual example, or, simply, that they felt no specific need to do so consistently reproducing photographs themselves never emerged as the authors' priority.

Notably, Brocq, Besnier, and Jacquet reproduce several images made after moulages in their 1900-4 texts. Entering into dialogue with paediatrician Parrot's identification of what he terms a 'lenticular syphilitic eruption', the authors publish a drawing of moulage 


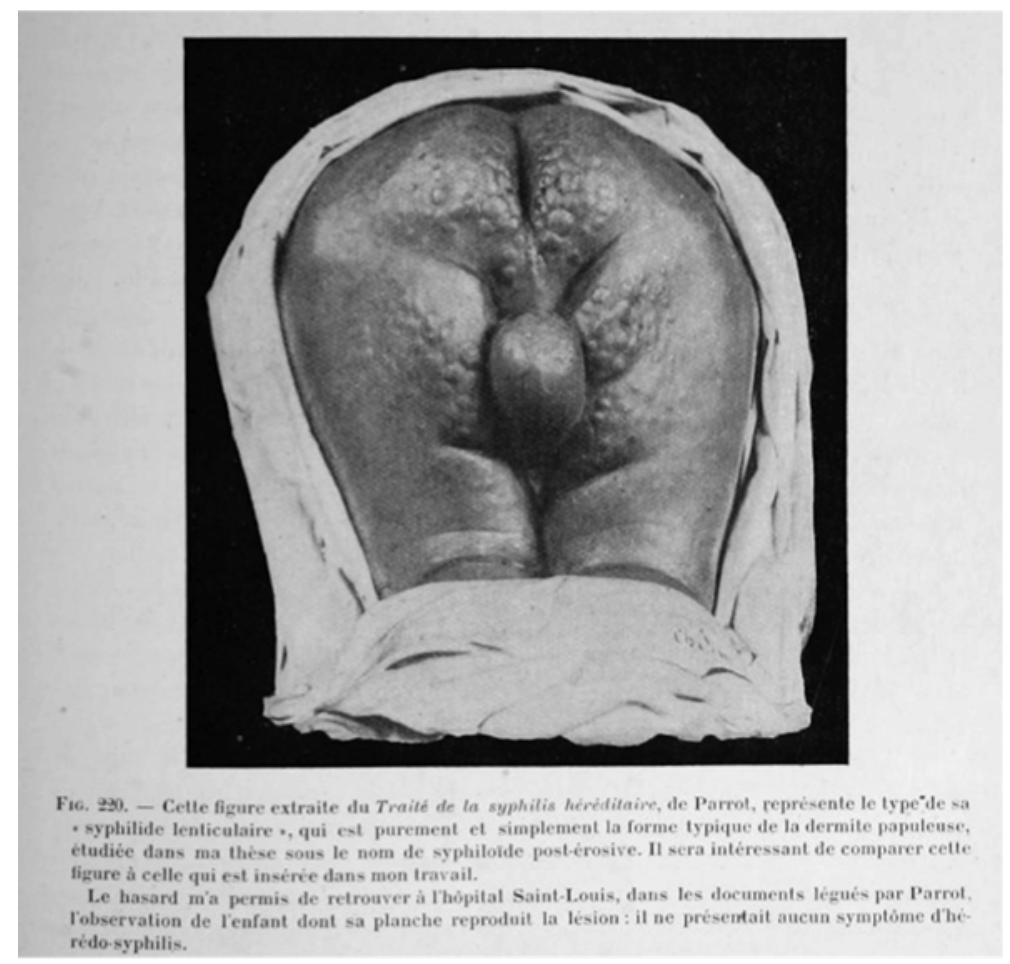

Figure 8: Fig. 220, 1886, drawing, published in Ernest Besnier, Louis Brocq, and Lucien Jacquet, La Pratique dermatologique, 1900-4. Source: gallica.bnf.fr/Bibliothèque Nationale de France.

number sixty-four, now in the collection of the Saint-Louis hospital (Figure 8). ${ }^{55}$ The moulage itself was commissioned by Parrot, fabricated by the mouleur Ch. Jumelin in 1880 , and had already been illustrated by the lithographer Renaudot in one of Parrot's own texts (Figures 9 and 10). ${ }^{56}$ The representation of Parrot's moulage printed in La Pratique dermatologique (Figure 8) shares formal elements with Fournier's and Méheux's images - namely, the striking black background juxtaposed with the bright white and grey tones of the moulage. Like Méheux's watercolours, the image serves to doubly mediate the patient's skin, which has already been once-represented by Jumelin. While the authors identify the image as a drawing, claiming that the image was taken from Parrot's own text, their reproduction diverges sharply from Renaudot's figure (Figure 10). Renaudot's lithograph exploits a soft hand, delicately modelled transitions from light to shade, and clear evidence of the artists' hand in the approximation of the white drapery framing the moulage and the darkening of the papules to aid the reader. Conversely, the drapery framing Brocq, Besnier, and Jacquet's representation almost identically matches the myriad folds and creases of the fabric strips framing the original moulage. Renaudot's shading here transforms into contrasts between reflected light and dark shadows that recall not the artist's hand, but rather early twentieth-century photography. The authors, therefore, either chose to reproduce the moulage photographically or employed an

55 Besnier, Brocq, and Jacquet, La pratique dermatologique, 1900, Vol. 1, 877.

56 Jules Parrot, La syphilis héréditaire et le rachitis: maladies des enfants (Paris: G. Masson, 1886), np. 


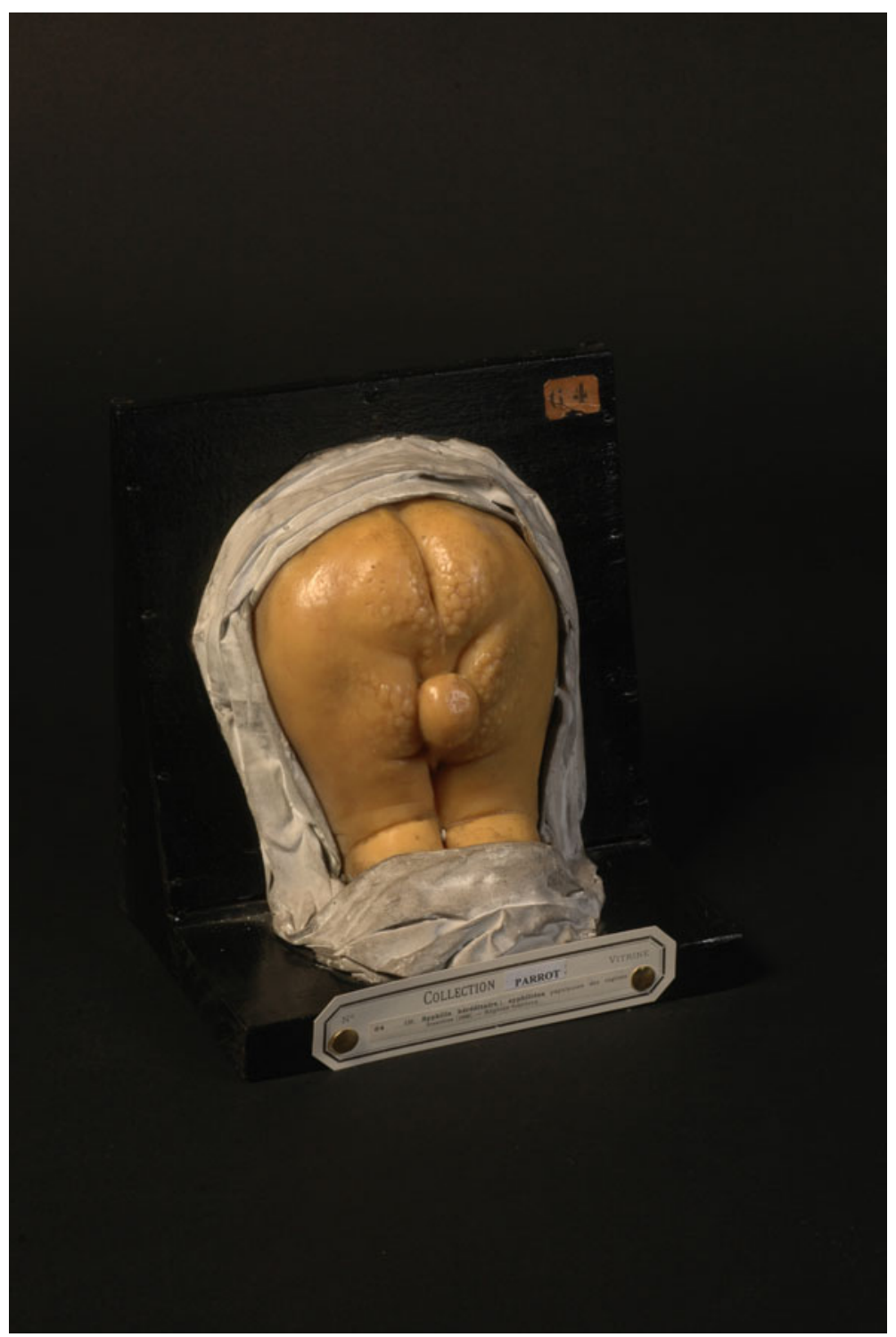

Figure 9: Ch. Jumelin, Syphilis héréditaire; syphilides papuleuses des régions fessières, 1880, wax moulage, Musée des Moulages, hôpital Saint-Louis, Paris. (C) F. Marin, P. Simon/Musée des moulages, Hôpital SaintLouis, AP-HP.

artist whose style mimicked the photographic. The glare emanating from the moulage echoes this, invoking the reflection of a photographic flash refracting off of the creamy, translucent wax surface. Significantly, the authors of La Pratique dermatologique employ the illustration to contend that Parrot misidentified the condition under discussion. Shoring up their argument that this child presented no more than a flare up of papular dermatitis, the authors write, 'Chance allowed me to find the observation of the child reproduced in this plate among the papers bequeathed to the Saint-Louis hospital by Parrot: he showed 


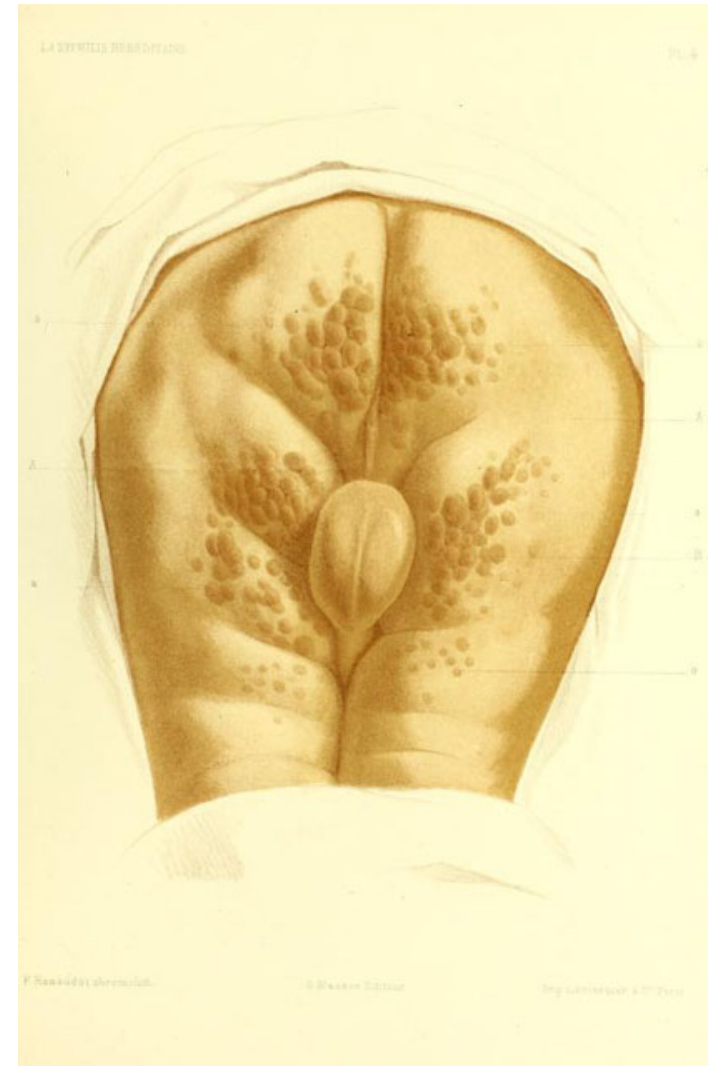

Figure 10: M. Renaudot, No Title, 1886, chromolithograph, published in Jules Parrot, La syphilis héréditaire et le rachitis: maladies des enfants, 1886. Source: Wellcome Collection, London

no signs of hereditary syphilis'. ${ }^{57}$ Once again, Brocq, Besnier, and Jacquet demonstrate that neither mechanical objectivity nor unflagging graphic fidelity grant authority to new medical hypotheses. Credibility is rather bolstered by the first-hand account left by Parrot coupled with the indexical, here illustrated by the triply rendered patient: through case study, moulage, and, if not a photograph of a moulage, an illustration accessioning visual conventions tied to the photographic.

In the two decades following publication of La Pratique dermatologique, Brocq's attitude towards photography changed dramatically. Just below his author credit in his 1921 Précis-Atlas de pratique dermatologique [Precise Atlas of Practical Dermatology], Brocq informs his reader that the text's eighty plates and 320 figures were created in collaboration with M. Schaller: the official photographer of the Saint-Louis hospital. ${ }^{58}$ The photographs selected for textual reproduction - such as Fig. 307 and Fig. 308, which both depict syphilids - again prioritise the description of the surface quality of the skin, the bumps and divots of the lesions and the scars they leave, and the wrinkling effect the eruption produces (Figure 11). Yet these images appear less abstract than Fournier's photographs with which I began this study. Perhaps the removal of the artificially produced

57 Besnier, Brocq and Jacquet, La pratique dermatologique, 1900, Vol. 1, 877.

${ }^{58}$ Louis Brocq, Précis-Atlas de pratique dermatologique (Paris: Gaston Doin, 1921), np. 


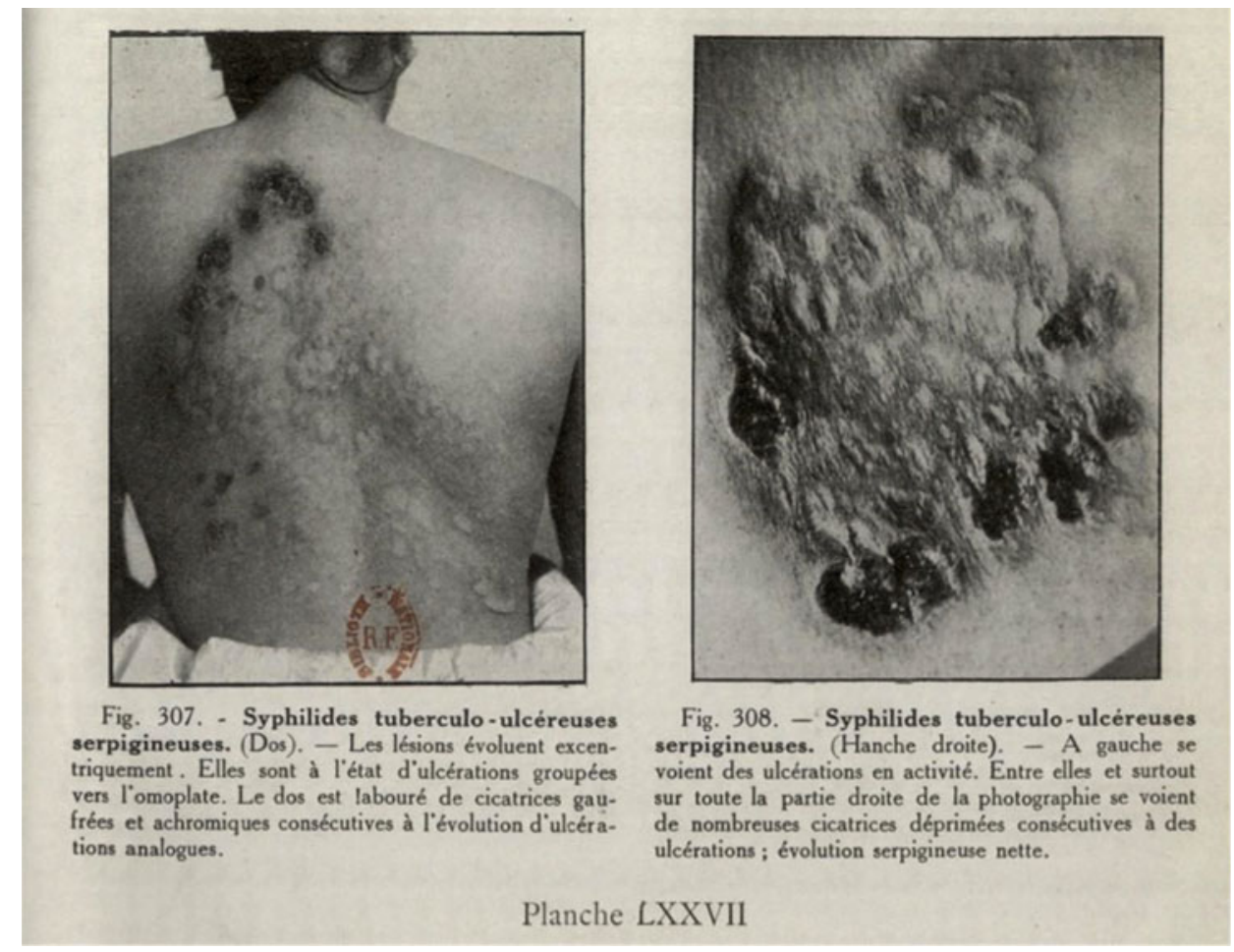

Figure 11: Schaller, Fig. 307 and Fig. 308, 1921, photograph, published in Louis Brocq, Précis-Atlas de pratique dermatologique, 1921. Source: gallica.bnf.fr/Bibliothèque Nationale de France.

black background contributes to this effect. The inclusion of quotidian details, like the wisp of hair lingering on the back of the patient's neck in Fig. 307, a patient's wrinkled shirt, or the simple chair and familiar black-and-white tiled floor that features in another similarly work to root these images in the reality of the dermatological hospital and clinic (Figure 12). This grounding of the medical photograph not in Fournier's, Saint-Hilaire's, or Méheux's abstracted and isolated world of scientific theorising but in the everyday experiences of both patients and physicians pushes the humanity of these patients to the fore and, ultimately, grants the images a degree of shock value.

Thus in his 1921 treatise, Brocq more directly underlines the photographic qualities of his images by both calling attention to Schaller's work as the official Saint-Louis photographer and by deploying images clearly grounded in the space of the dermatological clinic. Notably, this treatise was published after the development of the Wassermann test but before serological tests became reliable, and well in advance of the broad availability of penicillin and, thus, a cure. Brocq's more heavy-handed application of the rhetoric of the photographic, then, can be understood as tapping into burgeoning discourses of photography as surpassing fallible human vision, a dialogue that circulated widely within the scientific community from the 1880 s into the early decades of the twentieth century. The ability to photograph the microscopic and telescopic, the development of flesh-penetrating x-ray technology, and the creation of cameras that could isolate and fix a moment in time indistinguishable by the human eye contributed to a culture where 


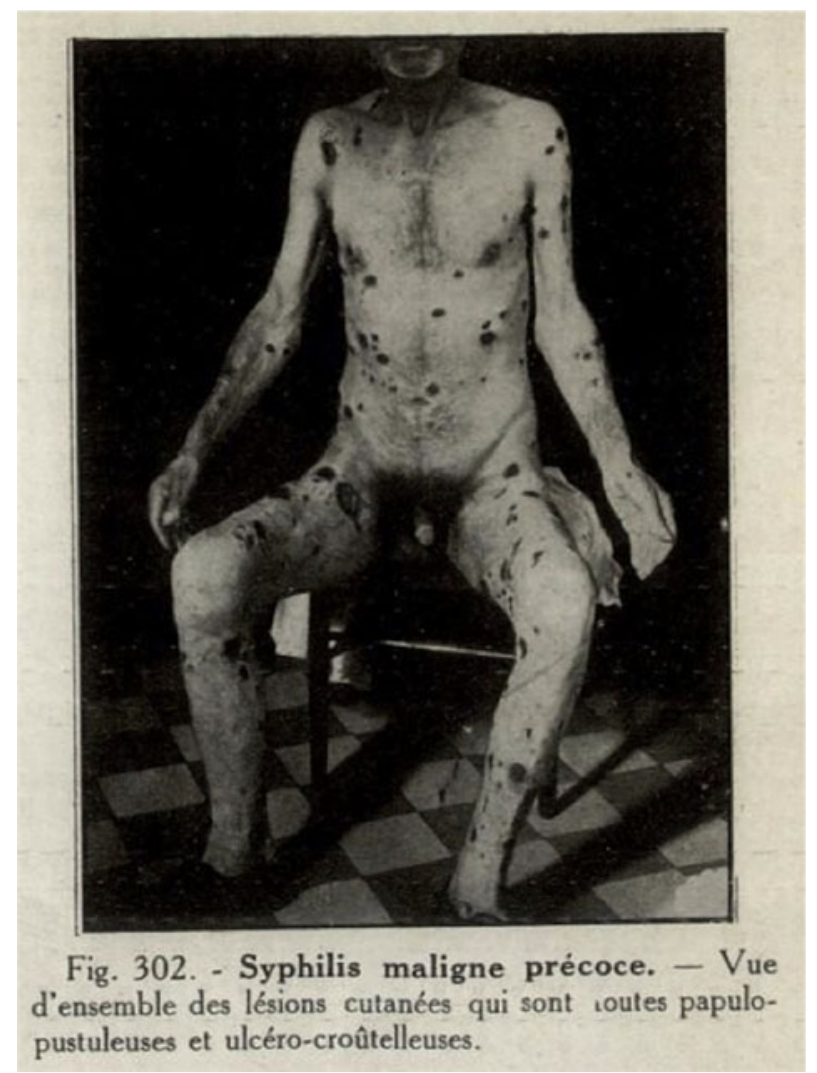

Figure 12: Schaller, Fig. 302, 1921, photograph, published in Louis Brocq, Précis-Atlas de pratique dermatologique, 1921. Source: gallica.bnf.fr/Bibliothèque Nationale de France.

photographic technologies could supersede human vision. ${ }^{59}$ Syphilis's optical uncertainty and the rise of unreliable, nonvisible modes of detection only exacerbated these tensions between syphilis and visuality among dermatovenereologists. It would seem that by more explicitly implicating the photographic, and thus the indexical, in these later texts, dermatologists such as Brocq bolstered the evidentiary power of their images in response to a growing distrust of human vision.

\section{Photographic Skin}

A return to Besnier, Brocq, and Jacquet's earlier volumes unveils an additional layer in the multivalent relationship among photography, indexicality, and representations of diseased skin: the photographic plate as analogous to the light-sensitive skin surface. In their discussion of tattoos, the authors state, 'For sailors, tattoos . . recount an important event that the subject participated in, a danger they have escaped (ex-voto), a voyage

59 Tom Gunning, 'Invisible Worlds, Visible Media', in Corey Keller (ed.), Brought to Light: Photography and the Invisible, 1840-1900, San Francisco Museum of Modern Art (New Haven, CT: Yale University Press, 2008), 51-63; Monica Bravo, 'Natural Photographs: Optograms and the Fiction of Captured Vision', History of Photography, 42, 1 (2018), 68. 
accomplished or a violent love, all things that photography replaces nowadays.... ${ }^{60}$ The authors' claim that by the turn of the century, photography replaced the memorial function of tattooing for sailors illuminates a direct link between printing on the skin - tattooing - and light imprinting on the photographic plate - photography. The invocation of the memorial function of both the tattoo and the photographic plate recalls photo-historian Geoffrey Batchen's claims for the interconnected haptic, memorial, and material properties of vernacular photography, arguably the category of photographic production the authors reference here. ${ }^{61}$ It is also worth emphasising that yet another line of connection is here drawn between the photograph, the skin, and the indexical. The index, it should be recalled, was not only in a 'dynamical connection' with the object represented, but also with the 'senses of memory for the person whom it served as sign'. In Brocq, Besnier, and Jacquet's estimation, tattoos and photographs both fulfil this role.

Brocq, Besnier, and Jacquet's writing contributed to a broader discourse equating the skin with the photographic plate that grew with the rise of phototherapy in the early twentieth century. Beginning in the 1890s, physicians began to study the healing effects of light - both natural (heliotherapy) and artificial (phototherapy). Though treating tuberculosis comprised the major focus of light therapy research, other dermatological conditions were well within the purview of phototherapy treatments. According to Tania Woloshyn, physicians believed that shining light on skin tissue bearing the symptoms of disease would 'stimulate the body's mechanisms, the tissues, organs and blood, and those internal processes that were signalled by external signs occurring on the surface, most notably through the on-going pigmentation of the skin', ultimately encouraging the skin and body to heal. ${ }^{62}$ Although Danish physician Niels Finsen is often credited with the early development of light therapy, his work was translated, published, and read widely internationally; phototherapy became popular practice in many parts of the world, including France. ${ }^{63}$ To administer his therapy, Finsen essentially created a dark room by covering all light-admitting openings with red cloth or glass to allow only the red spectra in. Finsen identified red light - the furthest from ultraviolet and violet light, the most destructive shades on the spectrum - as a mild, restorative treatment. Ultraviolet treatments, conversely, destroyed pathological symptoms through active chemical and antibacterial properties. To ensure the success of his therapies, Finsen placed photographic plates in his dark room and treatment facility to ensure that he had adequately blocked out the light. Finsen's use of the photographic plate demonstrates that he explicitly understood the skin in photographic terms. He wrote in one of his treatises, for example, that 'the skin during small-pox is as susceptible to daylight as a photographic plate, and must be kept from the chemical rays in the same way and almost as carefully'. ${ }^{64}$

Notably, Finsen illustrated this first book with before-and-after photographs that recorded the change light exposure made on the skin's surface. As Susan Sidlauskas

\footnotetext{
${ }^{60}$ Ernest Besnier, Louis Brocq, and Lucien Jacquet, La pratique dermatologique: traité de dermatologie appliquée, Vol. 4 (Paris: Masson et Cie, 1904), 436.

${ }^{61}$ Geoffrey Batchen, Each Wild Idea: Writing, Photography, History (Cambridge, MA: MIT Press, 2002), 61.

62 Tania Woloshyn, "Kissed by the Sun": Tanning the Skin of the Sick with Light Therapeutics, c. 1890-1930', in Jonathan Reinarz and Kevin Siena (eds), A Medical History of Skin: Scratching the Surface (London: Pickering \& Chatto, 2013), 181-2.

${ }^{63}$ Pierre Amblard, 'La Photo-Dermatologie', in Daniel Wallach and Gérard Tilles (eds), La Dermatologie en France (Toulouse: Editions Privat, Pierre Fabre Dermo-Cosmétique, 2002), 133. Finsen's articles began circulating in French translation in the 1890s; a French edition of his compiled writings was published there in 1899.

${ }^{64}$ Finsen qtd. in Woloshyn, 'Kissed by the Sun', 183.
} 
has argued, the before-and-after format was a particularly fraught yet legible mode of image production in turn-of-the-century medicine; before-and-after photographs had to look similar enough to confirm the continuity of subjects between images, yet different enough to demonstrate substantive change. ${ }^{65}$ Photography's indexicality is, therefore, once again operative, confirming presence before medicalised bodies at different moments and, therefore, substantiating claims for change over time. In the case of light therapy in particular, Woloshyn asserts that physicians largely considered pigmentation a sign of advancement and a positive prognosis. ${ }^{66}$ By the early 1900s, a practitioner as powerful as Louis Landouzy, dean of the Paris medical school, voiced support for phototherapy and the visible changes it made to the skin, claiming 'pigmentation is the barometer of the suncure'. ${ }^{67}$ Although Finsen's work largely focused on tubercular patients, phototherapy was also discussed as a potential treatment for syphilis. Dr René-Denis Horand, for example, noted 'chancres [of the face], under these therapeutic methods [light therapy], rapidly healed by scar formation'. ${ }^{68} \mathrm{He}$ bolstered this argument with a laboratory observation: that preparations of Treponema bacteria - the genus in which the spirochetes that cause syphilis are classified - grown up in the dark teem with more living organisms than do plates prepared in the light of day. ${ }^{69}$

In certain ways, the rhetoric of phototherapy harkens back to images like Brocq's Fig. 308 or even Fournier's photographs, where the patient's body extends beyond the photograph's frame. This composition visually isolates the pathological patch of skin from its anatomical location (in Brocq's case, the right hip) and transforms the photograph into an isolated and abstracted fixed swatch of skin. In the case of both light therapy and photography, this swatch would subsequently be exposed to light. This fixing of the skin on the plate recalls Oliver Wendell Holmes's - a physician himself - understanding of photography as capturing one of the millions of films or skins constantly shed by bodies and objects. ${ }^{70}$ For Holmes, surface begets surface and skin becomes photograph. Phototherapists' conceptual equation of the skin and the photographic plate, however, transcends this visual transformation. It brings dermatovenereologists' concerns with indexicality to the fore, proposing that photographs of diseased skin are materially analogous to the skin itself.

I do not want to suggest that the physicians composing or guiding the production of these photographs misunderstood the difference between the skin and the plate; rather, I posit that the skin and the plate were conceived of as morphological equivalents. Both the skin and the plate shared photosensitivity. As the photograph indexes the skin it represents, the visual symptoms of disease can also be understood as indices of infection. In the case of syphilis, for example, chancres, rashes, and other visual symptoms - if mercurial and dissimulating - index the underlying infection. This parallel would have been particularly evident in the case of syphilitic skin, where tensions between invisible latency and visual

\footnotetext{
${ }^{65}$ Susan Sidlauskas, 'Before and After: The Aesthetic as Evidence in Nineteenth-Century Medical Photography', in Jordan Bear and Kate Palmer Albers (eds), Before-and-After Photography: Histories and Contexts (London and New York: Bloomsbury, 2017), 31-2.

66 Woloshyn, 'Kissed by the Sun', 184.

${ }^{67}$ Louis Landouzy qtd. in Woloshyn, 'Kissed by the Sun', 185.

${ }^{68}$ René-Denis Horand, Syphilis et cancer, cancer sur syphilis ou cancer juxtasyphilitique (Paris: J.-B. Baillière et fils, 1908), 27-8.

69 Ibid., 28.

${ }^{70}$ Oliver Wendell Holmes, “The Stereoscope and the Stereograph” 1859, an Excerpt', in Vicki Goldberg (ed.), Photography in Print: Writings from 1816 to the Present (Albuquerque, NM: University of New Mexico Press, 1988), 100-1.
} 
manifestation inherently reoccurred throughout the disease's clinical course, mirroring the photographic image's initial latency on the photographic plate, which is only brought to the surface through developing processes. What's more, while syphilitic rashes and the scarring these eruptions might leave would evoke certain emotions or recollections for the patient, physicians' representations of dermatological illness were tied to specific case studies or memories of particular iterations of illness, examination, and treatment. Thus, both diseased skin and dermatological photographs alike perform the memorial function of the index. It is subsequently possible that these material and morphological linkages between syphilitic skin and dermatological photographs amplified the 'having-been-there' quality of the photographic, making its verbal and visual rhetoric even more compelling. Thus, while scholars have previously called attention to the materiality of moulages, particularly the visual and haptic qualities of wax, whose translucent tones mimicked myriad dermatological textures and would feel warm to the touch, the materiality of the photograph, which mirrored the materiality of the skin in diverse ways, may have likewise served to bolster its evidentiary value. ${ }^{71}$

\section{Conclusion}

As we have seen, the objectivity of moulages and dermatological photographs, as well as a clear divide or hierarchy between them, is not as straightforward as has previously been described. Physicians frequently pointed to multiple kinds of evidentiary media, much of it subjectively produced, as evidence. Constellations of moulages, photographs, and first-hand descriptions hung together and cohered to collaboratively construct medical information. Indexicality was what certified images' value as visual evidence. In the case of fin-de-siècle dermatovenereology, indexicality was metaphorically articulated as a 'bearing witness' to the idiosyncratic, pathological example represented, and deeply allied, as Zervigón and Kriebel have demonstrated, with cultural conceptions of the photographic. For these fin-de-siècle authors, the indexical could be cleaved from the objective; as we have seen, it was frequently aligned with heavily mediated photographs and subjectively produced moulages. Such a conclusion is significant for historians of scientific image making broadly speaking, as it illuminates a case where photographic objectivity is divorced from one of the qualities most routinely cited as certifying that same objectivity. ${ }^{72}$

Returning to dermatovenereology, by deploying indexical images, physicians harnessed the visual and verbal rhetoric of the photographic and all of its cultural baggage - links to mechanical objectivity, scientific authority, and certain kinds of evidentiary truth - to the images deployed in their atlases, treatises, and teaching collections. That they would do so meshes with broader analyses of the appeal of the photograph and the photographic in later nineteenth-century scientific circles; Daston and Galison illuminate just such a tendency, writing that 'photographs were preferred for subject matter that might arouse skepticism - because it was rare or spectacular or controversial. ${ }^{73}$ Syphilis, though not rare, was certainly controversial, especially given its status as a hereditary disease and

\footnotetext{
${ }^{71}$ For writing about wax and the compelling materiality of moulages, see Hunter, 'Effroyable Réalisme', 45 and Georges Didi-Huberman, 'Wax flesh, vicious circles', in Monika von Düring and Marta Poggesi (eds), Encyclopaedia Anatomica: A Complete Collection of Anatomical Waxes (Köln and New York: Taschen, 1999), 66.

72 See, for example, Daston and Galison, Objectivity, 135, where 'objective' is used as a synonym for 'indexical'.

73 Daston and Galison, Objectivity, 135.
} 
the threat it posed to future French generations. Considered in this broader context, the allure of the index gains traction. The indexical relationship between patient and image fulfils dermatologists' desires to visually arrest the perpetually shifting markers of syphilis and facilitated future communications about distinct case studies, serving as individual reminders of past patients. Displayed together in an atlas or teaching museum, they created a veritable public archive of memories, demonstrating the scope of potential symptomatic presentation. But more than this, these images attested to the existence of controversial cases at a moment ensconced in the early eugenics movement, when diseases communicated through inheritance were understood as particularly detrimental for both individual families and the state. The representational strategies employed by dermatological image-makers addressed this anxiety and doubt by formally and materially yoking these objects - via the photographic and the indexical - to the represented body and its particular idiosyncratic manifestation of syphilitic symptoms. Fin-de-siècle dermatologists thus rendered these images more powerful signifiers of the crisis syphilis posed to an audience that truly mattered: physicians in training, the future intermediaries between medical research and the general population, and the future organisers of public health campaigns. 